\title{
Fetal rat lung epithelium has a functional growth hormone receptor coupled to tyrosine kinase activity and insulin-like growth factor binding protein-2 production
}

\section{C Batchelor, R M Lewis, B H Breier, P D Gluckman and S J M Skinner}

Research Centre for Developmental Medicine and Biology, Faculty of Medicine and Health Science, University of Auckland, Private Bag 92019, Auckland, New Zealand

(Requests for offprints should be addressed to S J M Skinner)

\begin{abstract}
Although growth hormone $(\mathrm{GH})$ receptor (GHR) mRNA and protein are present in fetal tissues such as the lung, there is little evidence that GH mediates growth in the fetus. We have identified functional responses to $\mathrm{GH}$ in fetal rat lung epithelia and suggest a possible role for GHR in the developing lung. GHR mRNA in lung extracts was high before birth at day 16 of gestation (16f), decreased to low levels at day $22 \mathrm{f}$ but increased again after birth. At day 20f GHR mRNA levels were higher in lung than in liver, whereas growth hormone binding protein mRNA levels were approximately equal in lung and liver. Stimulation of primary cell cultures of day 19f lung epithelia with GH caused increased
\end{abstract}

tyrosine phosphorylation in specific proteins, demonstrating functional GHR. Lung fibroblasts isolated at the same time did not respond to GH. Ligand and Northern blot analysis of the epithelial cultures revealed that $\mathrm{GH}$ stimulation increased insulin-like growth factor binding protein-2 (IGFBP-2) activity and mRNA. These experiments demonstrate the functional activity of GHR, specifically in fetal lung epithelium. We suggest that one role for GH in vivo may be indirectly to modify insulin-like growth factor activity in the developing fetal lung by increasing IGFBP-2.

Fournal of Molecular Endocrinology (1998) 21, 73-84

\section{INTRODUCTION}

In postnatal life growth hormone $(\mathrm{GH})$ is a primary regulator of development. Its effects upon growth are predominantly mediated by insulin-like growth factor-I (IGF-I) (Edmondson et al. 1995, Jones \& Clemmons 1995). Despite high levels of circulating $\mathrm{GH}$, up to 150 and $300 \mathrm{ng} / \mathrm{ml}$ in human and rat fetuses respectively (Kaplan et al. 1972, Rieutort 1974), no substantial role for $\mathrm{GH}$ has been established in the fetus.

In the human fetus the absence of $\mathrm{GH}$ causes a slight decrease in fetal length (Gluckman et al. 1992) but weight is not affected. The absence of GH receptor (GHR) in Laron syndrome babies is associated with variation in the size and length of the newborn. However, malformations have also been identified and may contribute to asymmetric growth (Rosenbloom et al. 1992, Rosenfeld et al. 1994).

$\mathrm{GH}$ also has different effects in fetal life in animal models. Transgenic mice expressing high levels of
GH have normal birth weights (Palmiter et al. 1983, Searle et al. 1992) but dwarf rats without GH, although normal in length at birth, have lower body weights when compared with their normal litter mates (Kim et al. 1993).

Postnatally, GH has distinct metabolic effects in a number of tissues. For example, in adipocytes GH regulates lipid breakdown and glucose release (Foster et al. 1988). Thus, it is possible that GH in the fetus has more to do with metabolic regulation than with longitudinal growth. Despite the lack of evidence of a role for GH in fetal growth, GHR and growth hormone binding protein (GHBP) mRNA and protein have been found in many fetal tissues, including lung epithelia, by immunohistochemistry and in situ hybridisation on tissue sections (GarciaAragon et al. 1992, Edmondson et al. 1995). However, these studies have not differentiated between the receptor and the binding protein, nor have they identified any distinct function for the GHR. 
The IGFs and insulin-like growth factor binding proteins (IGFBPs) are present in the fetal and neonatal lung and are regulated in time with the periods of lung growth (Han et al. 1987, Batchelor et al. 1995). It is also during these periods that the lung undergoes dramatic changes in carbohydrate and lipid composition and it has been reported that $\mathrm{GH}$ has effects on glycogen metabolism in fetal lung epithelia near term (Jost et al. 1979, Bourbon \& Jost 1982, Mendelson \& Boggaram 1991). Thus, the fetal lung may provide a good model to elucidate a metabolic or growth regulating role for $\mathrm{GH}$ in the fetus.

The objective of this study was to test the hypothesis that GHR is present and functional in the lung during the perinatal period. GHR mRNA as distinct from the GHBP mRNA was measured in lung tissues before and after birth. Evidence for a functional GHR was sought using an in vitro approach to identify changes in phosphorylation and possible effects on the regulation of IGFs, IGFBPs and surfactant caused by GH stimulation.

\section{MATERIALS AND METHODS}

\section{Chemicals and radiochemicals}

Unless otherwise stated all chemicals were obtained from Sigma Chemical Company (St Louis, MO, USA). Radiochemicals were obtained from Amersham International (Amersham, Bucks, UK).

\section{Labelled probes}

The rat IGFBP-2 cDNA used in these studies was as described previously (Brown et al. 1989, Batchelor et al. 1995) and was kindly supplied by M M Rechler (NIH, Bethesda, MD, USA). The specific fragment corresponded to nucleotides 502 to 1087 of the coding region. The rat $\mathrm{GH}$ receptor/binding protein cDNA was as described previously (Baumbach et al. 1989) and was kindly supplied by W R Baumbach (American Cyanamid Co., Princeton, NJ, USA). The specific fragment corresponded to nucleotides -11 to 788 of the coding region which is common to both the $4.7 \mathrm{~kb}$ GHR and the $1.8 \mathrm{~kb}$ GHBP mRNA. The $1.8 \mathrm{~kb}$ surfactant protein A (Sp-A) cDNA probe, kindly supplied by S Buch (Hospital for Sick Children, Toronto, Ontario, Canada), was as described previously (Buch et al. 1991, Batchelor et al. 1995).

The IGFBP-2, Sp-A and GHR/GHBP probes $(50 \mathrm{ng})$ were labelled with $\left[{ }^{32} \mathrm{P}\right] \mathrm{dCTP}$ for Northern blot analysis using the random primers labelling system as described by the manufacturer (GibcoBRL, Grand Island, NY, USA).
Single-stranded ${ }^{32} \mathrm{P}$-labelled probes for IGF-I (Lowe et al. 1988), for cyclophilin (Jakubowski et al. 1991) and for GHR/GHBP (Butler et al. 1996) were used in an RNAse protection assay as described previously (Batchelor et al. 1995, Butler et al. 1996). RNAse digestion resulted in fragments of 224 bases for the IGF-I, 300 bases for cyclophilin and 439 and 290 bases corresponding to full length GHR and GHBP mRNA respectively.

\section{Animal tissues}

Ethical agreement was obtained for animal use from the Animal Ethical Committee, University of Auckland, New Zealand. Date-mated female rats had food available ad libitum. Fetal tissues were obtained at days 16, 18, 20 and 22 (term) of gestation from dams killed by halothane overdose. Neonates were obtained on days 1, 3, 5, 9, 15 and 21 after birth. All fetuses or neonates were obtained between 0900 and $1030 \mathrm{~h}$. Fetal tissues for RNA extraction were frozen in liquid nitrogen immediately after excision and stored at $-80{ }^{\circ} \mathrm{C}$. Lung tissues for cell culture were placed in cold sterile minimal essential medium (MEM) (Gibco-BRL).

\section{Cell culture}

Fetal lung epithelial cell and fibroblast cultures were prepared as described previously (Batchelor et al. 1995). Briefly, lung tissues were dissected out and placed in cold Hanks' balanced salt solution (without $\mathrm{Mg}^{2+}$ or $\mathrm{Ca}^{2+}$ ) then cut into 1-2 $\mathrm{mm}^{3}$ pieces. The lung pieces were digested for $15 \mathrm{~min}$ at $37^{\circ} \mathrm{C}$ in trypsin $(500 \mu \mathrm{g} / \mathrm{ml}$; Boehringer Mannheim, Mannheim, Germany). Deoxyribonuclease I $(100 \mu \mathrm{g} / \mathrm{ml}$; Boehringer Mannheim) was then added and the incubation continued for $10 \mathrm{~min}$. After filtering the cells, MEM supplemented with 10\% fetal bovine serum (FBS) was added and the mixture centrifuged ( $300 \mathrm{~g}, 15 \mathrm{~min})$. The pellet was resuspended in MEM plus $10 \%$ FBS, placed in plastic culture flasks and the cells incubated at $37^{\circ} \mathrm{C}$ for $15 \mathrm{~min}$ to allow the adherence of fibroblasts. The supernatant containing mixed lung cells was collected and centrifuged three times ( $200 \mathrm{~g}, 3 \mathrm{~min})$, resuspending the pellet each time in fresh medium before replating into culture flasks and incubating for $90 \mathrm{~min}$. Non-adherent cells were then removed after vigorous swirling and replated at approximately $1 \times 10^{5} \mathrm{cells} / \mathrm{cm}^{2}$. These were predominantly epithelial $(>90 \%)$ with little mesenchymal contamination (Skinner et al. 1991). Cells were then allowed to recover for $24 \mathrm{~h}$ in MEM plus $10 \%$ FBS (Gibco-BRL). 


\section{Conditions for growth hormone stimulation in vitro}

Medium was replaced with MEM supplemented with $1 \% \mathrm{FBS}$ and incubated for a further $16 \mathrm{~h}$. The cells were washed then incubated for $1 \mathrm{~h}$ in serum-free MEM. For phosphorylation studies bovine (b) GH (3-300 ng/ml, a gift from W R Baumbach, American Cyanamid Co.), vehicle control or $3 \mathrm{ng} / \mathrm{ml}$ human epidermal growth factor (hEGF) were added and the cells were incubated for $0,1,3$ and $10 \mathrm{~min}$ before extraction. In some experiments cells were left for a further $24 \mathrm{~h}$ and medium collected for ligand (Hossenlopp et al. 1986) and Western analyses and the cells processed for RNA extraction.

In some experiments the medium was replaced with either MEM with $10 \%$ FBS or MEM with $1 \%$ FBS and incubated for a further $16 \mathrm{~h}$. The $10 \%$ or $1 \% \mathrm{FBS} / \mathrm{MEM}$ was then replaced with fresh medium. For the serum-free experiments MEM with 1\% FBS was replaced with MEM (without FBS $)$. bGH $(100 \mathrm{ng} / \mathrm{ml})$ or vehicle control was added and the cells incubated for $24 \mathrm{~h}$. Medium was collected and cells processed for RNA extraction.

\section{RNA analysis of whole lung and cell culture}

Frozen tissues from fetuses or neonates were homogenised and extracted using TRIzol (GibcoBRL) following the manufacturer's protocol to provide total RNA samples. For cell cultures, medium was aspirated and the cells covered in TRIzol. The cells were scraped immediately, homogenised and the RNA extracted.

Northern blot analysis was as described previously (Batchelor et al. 1995). Briefly, samples of total RNA $(10 \mu \mathrm{g})$ were separated using denaturing $1 \%$ agarose gels and blotted onto nylon membranes (Hybond- $\mathrm{N}^{+}$; Amersham International) according to the manufacturer's instructions. 28S RNA was visualised by staining with methylene blue and analysed for integrity and evenness of loading as described previously (Tijssen 1993, Currie et al. 1996). Hybridisation conditions for IGFBP-2 and $\mathrm{Sp}-\mathrm{A}$ were as described previously (Klempt et al. 1992, Batchelor et al. 1995). For GHR/GHBP the membrane was washed once for $30 \mathrm{~min}$ in $2 \times \mathrm{SSC}$ at $20{ }^{\circ} \mathrm{C}$ and then once for $30 \mathrm{~min}$ with $2 \times \mathrm{SSC} /$ $0 \cdot 1 \% \operatorname{SDS}$ at $60{ }^{\circ} \mathrm{C}$ and exposed to $\mathrm{X}$-ray film. Northern blots were performed three or more times.

RNAse protection assays were carried out as described previously (Batchelor et al. 1995, Butler et al. 1996). Briefly, aliquots $(20 \mu \mathrm{g})$ were hybridised with an excess of each labelled probe. Nonhybridised RNA was removed by digestion with
RNAse. The remaining protected fragments were electrophoresed through a denaturing $8 \%$ acrylamide gel, the gel dried and exposed to X-ray film. RNAse protection assays were performed three or more times.

\section{Tyrosine phosphorylation assay}

The tyrosine phosphorylation assay was a modification of the procedure described by Clayton et al. (1994). Medium was removed and cells scraped in lysis buffer (1\% deoxycholic acid, $1 \%$ Triton X-100, $0 \cdot 15 \mathrm{M} \mathrm{NaCl}$ and $50 \mathrm{mM}$ Tris- $\mathrm{HCl} \mathrm{pH}$ 7.4) which contained protease and phosphatase inhibitors (20 mM EDTA, 1.0 mM phenyl methyl sulphonyl fluoride (PMSF), $2.0 \mathrm{mM}$ N-ethylmaleimide (NEM), $5.0 \mathrm{mM}$ benzamidine hydrochloride and $\left.1 \mathrm{mM} \quad \mathrm{Na}_{3} \mathrm{VO}_{4}\right)$. The lysates were centrifuged $(100000 \mathrm{~g})$ at $4{ }^{\circ} \mathrm{C}$ and the supernatants mixed 1:1 with reducing sample buffer, heated to $100{ }^{\circ} \mathrm{C}$ for $5 \mathrm{~min}$ and frozen at $-70{ }^{\circ} \mathrm{C}$. Samples were separated through a $7 \cdot 5 \%$ polyacrylamide gel and blotted onto nitrocellulose membranes (Schleicher and Schuell, Keene, NH, USA). Protein was visualised with Fast Green $(0 \cdot 1 \%$ in $1 \%$ acetic acid) to determine evenness of loading and destained with $0.01 \mathrm{M} \mathrm{NaOH}$. Blots were blocked with 3\% BSA, washed in Tris-buffered saline with Tween (TBS-T, $20 \mathrm{mM}$ Tris-HCl, $137 \mathrm{mM} \mathrm{NaCl}, 0 \cdot 05 \%$ Tween) then incubated with a 1:2500 dilution anti-phosphotyrosine antibody (PY20, Santa Cruz Biotechnology, Santa Cruz, CA, USA). Immunopositive bands were then detected using enhanced chemiluminescence (ECL, Amersham ECL; Amersham International) following the manufacturer's protocol. Tyrosine phosphorylation assays were repeated three or more times.

\section{Ligand and Western blot analyses of IGFBPs}

IGF binding proteins in cell media were estimated by ligand blot (Hossenlopp et al. 1986). Briefly, to freshly obtained cell medium, protease inhibitors (20 mM EDTA, 1.0 mM PMSF, 2.0 mM NEM, $5.0 \mathrm{mM}$ benzamidine hydrochloride) were added and the medium dialysed against $100 \times$ volume Milli-Q water $\left(2\right.$ changes) over $36 \mathrm{~h}$ at $4{ }^{\circ} \mathrm{C}$. The dialysate was then lyophilised, resuspended in water and the protein concentration was determined by modified Lowry assay (Markwell et al. 1978) and found to be approximately equal. Samples (10 $\mu \mathrm{g}$ protein) were separated on $12 \%$ polyacrylamide gels under non-reducing conditions and blotted onto nitrocellulose membranes. The IGFBPs on the blot were renatured with 3\% Tween 20 in TBS, blocked with $1 \%$ BSA and incubated with ${ }^{125}$ I-IGF-II 
at $4{ }^{\circ} \mathrm{C}$ for $16-24 \mathrm{~h}$. Unbound ${ }^{125} \mathrm{I}-\mathrm{IGF}-\mathrm{II}$ was removed by washing in TBS-T. The membrane was placed on X-ray film (Kodak XAR) at $-80{ }^{\circ} \mathrm{C}$ for $24-72 \mathrm{~h}$ and the film developed. The intensity of the autoradiographic signal of the $32 \mathrm{kDa}$ band (identified as IGFBP-2 by immunoblotting) was determined using a scanning densitometer (Molecular Dynamics, Sunnyvale, CA, USA).

For Western analysis, the nitrocellulose membranes used for ligand analysis were submerged in stripping buffer (100 mM 2-mercaptoethanol, 2\% SDS, $62.5 \mathrm{mM}$ Tris- $\mathrm{HCl} \mathrm{pH} 6.7$ ) at $50{ }^{\circ} \mathrm{C}$ for $30 \mathrm{~min}$, washed 2 times for $10 \mathrm{~min}$ in TBS-T then blocked with $3 \%$ BSA in TBS-T. Blots were then incubated with a 1:2000 dilution of a rabbit polyclonal anti-bovine IGFBP-2 antibody (Upstate Biotechnology Incorporated, Lake Placid, NY, USA). Immunopositive bands were then detected using ECL, exposed to film for $10 \mathrm{~min}$ and quantified using a scanning densitometer.

\section{Statistics}

All experiments were done $\geq 3$ times except for the IGFBP-2 ligand and Western blots which were done twice. The density of autoradiograph bands and image analysis of methylene blue scans were compared between different days of development by ANOVA. Differences between control and stimulated groups and between lung and liver samples were performed by Student's $t$-test. Differences between control and stimulated groups with different serum concentrations were determined by ANOVA.

\section{RESULTS}

\section{The ontogeny of GHR in lung during the perinatum}

The presence and abundance of mRNA encoding the GHR were determined in rat lung tissues during development. The pooled lung tissue from single litters ( $n=6$ litters for each time point) were collected on fetal (f) days 16, 18, 20, 22 of gestation and neonatal $(\mathrm{d})$ days $1,3,5,9,15$ and 21. This sampling regime was designed to span the phases of lung growth and differentiation which included the canalicular, saccular and alveolar phases of lung development (Buch et al. 1991). The relative abundance of the $4.7 \mathrm{~kb}$ GHR mRNA was high on day $16 \mathrm{f}$ decreasing to the lowest level on $22 \mathrm{f}$ ( $58 \%$ of the levels on day $16, P<0 \cdot 05, n=6$ ), but by day 9 after birth had returned to the high levels seen on day 16 f (Fig. 1). The 28S RNA levels in this and all subsequent Northern blots were determined by
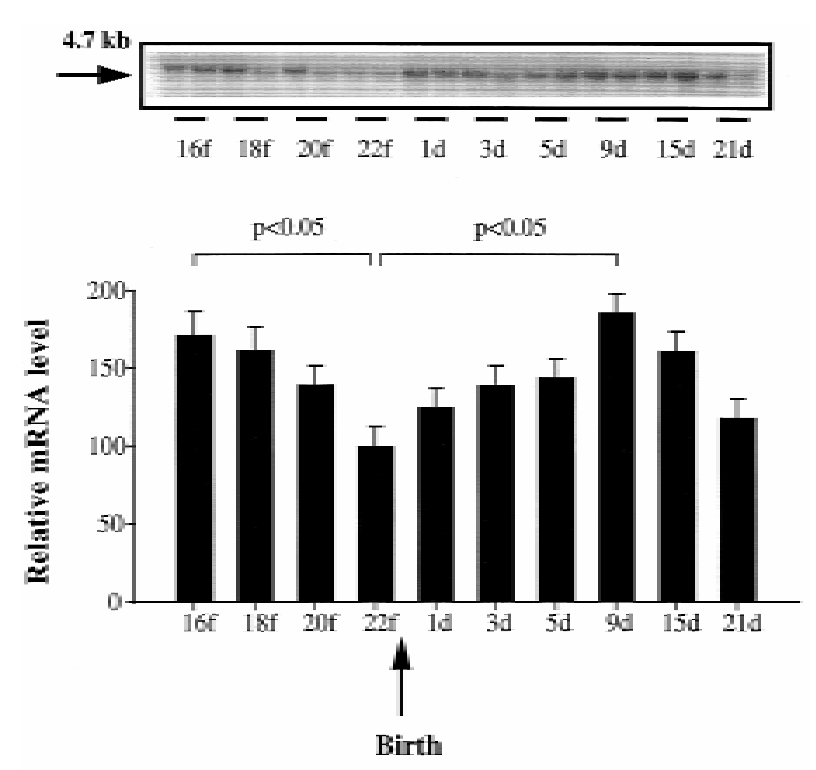

285

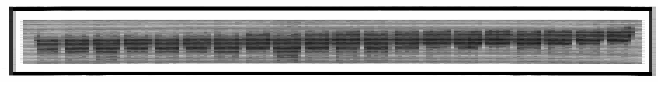

FIGURE 1. The ontogeny of GHR in fetal and neonatal rat lung tissues. Aliquots $(20 \mu \mathrm{g})$ of total RNA extracts from lung tissues were separated on denaturing 1\% agarose gels, transferred to nylon membrane, probed with ${ }^{32} \mathrm{P}$-labelled probe for GHR, washed to the appropriate stringency and autoradiographed. The autoradiographs were analysed by scanning densitometry and the values for the $4.7 \mathrm{~kb}$ GHR mRNA band are presented in the histogram relative to the values for the methylene blue stained 28S RNA (in arbitrary units). The histogram shows that GHR mRNA levels were high on day $16 \mathrm{f}$, decreased to a minimum on day $22 \mathrm{f}$ $(60 \%$ of day $16 \mathrm{f}, P<0 \cdot 05, n=6)$ and increased after birth to approximately the original level by $9 \mathrm{~d}(P<0 \cdot 05, n=6)$.

methylene blue staining and were found to be relatively constant.

\section{Relative abundance of GHR and GHBP mRNA in lung and liver}

In order to determine the potential of the lung for generating GHR and GHBP we compared the mRNA levels of the lung to those of the liver on day 20 of gestation. Earlier reports indicated low levels of GHR in the fetal liver (Edmondson et al. 1995). Therefore, we elected to use the more sensitive RNAse protection analysis to compare GHR and GHBP mRNA levels between the two organs, using cyclophilin which is equally expressed in the lung and the liver as a loading control (Danielson et al. 1988, Jakubowski et al. 1991). In the lung there was a $50 \%$ higher level of GHR mRNA expression than in the liver $(P<0.05$, Table 1$)$ but GHBP mRNA 
TABLE 1. GHR and GHBP mRNA abundance in lung and liver from fetal day 20 rats expressed as a percentage (means \pm s.D.) in relation to $G H R$ in fetal liver

$\begin{array}{llll} & \text { GHR } & \text { GHBP } \\ \text { Lung } & 155 \cdot 3 \pm 15 \cdot 4 * & & 75 \cdot 8 \pm 8 \cdot 1 \\ \text { Liver } & 100 \cdot 0 \pm 20 \cdot 7 & & 77 \cdot 2 \pm 8 \cdot 6\end{array}$

* $P<0 \cdot 05$ compared with fetal liver.

RNAse protection analysis of fetal lung and liver: total RNA samples from day 20 fetal lung or liver ( $n=6$ for each tissue) were hybridised with a ${ }^{32} \mathrm{P}$-labelled antisense probe for GHR/GHBP. The densitometric measurements of autoradiographs were normalised against the loading control, ${ }^{33} \mathrm{P}$-labelled cyclophilin, and expressed as a percentage in relation to fetal liver GHR.

expression was not significantly different between these two tissues. Thus the abundance of the GHR and GHBP mRNA is different, suggesting organspecific regulation of expression of GHR and GHBP.

\section{GHR and IGF-I expression in rat fetal lung cultures}

To characterise further a function for GHR in the fetal lung, we pursued an in vitro approach using primary cell cultures of isolated fetal lung epithelia and fibroblasts. Lung fibroblasts and epithelial cells were prepared from fetuses at day 19f. Analysis of total RNA by Northern blotting after 3-4 days in culture demonstrated that both the epithelia and fibroblasts had low levels of GHR mRNA when compared with whole lung from day 19 fetuses. IGF-I mRNAs were detected in the fibroblasts but there was no detectable expression in epithelia as reported previously (Han et al. 1987, Stiles \& Moats Staats 1989).

\section{Tyrosine kinase response to $\mathrm{GH}$ in fetal lung cells}

Upon GH binding, the GHR forms a dimer complex which induces tyrosine phosphorylation of a number of intracellular proteins. In order to identify functional GHR activity in fetal lung we investigated tyrosine phosphorylation activity of the primary cell cultures of fetal lung epithelia separately from fetal lung fibroblasts. For this study we used stimulation with EGF as a positive control (Warburton et al. 1992). Primary cell cultures of fetal rat lung fibroblasts and epithelial cells were prepared from fetuses at day 19f. Cells were incubated with bGH $(100 \mathrm{ng} / \mathrm{ml})$, hEGF $(3 \mathrm{ng} / \mathrm{ml})$ or vehicle control for $0,1,3$ and $10 \mathrm{~min}$. Cell proteins were then extracted and analysed for
Epithelia

Fibroblasts
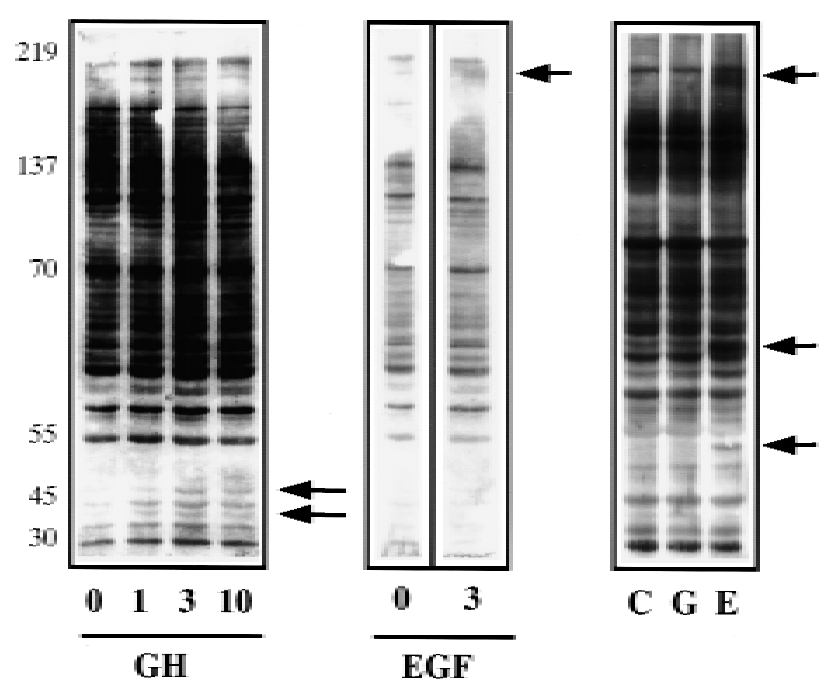

FIGURE 2. Tyrosine kinase response to bGH and EGF in fetal lung epithelia and fibroblasts in vitro. Lung tissues were dissected and epithelial and fibroblasts cells prepared as described in Materials and Methods. Cells were preincubated in serum-free medium for $1 \mathrm{~h}$ then treated with bGH $(100 \mathrm{ng} / \mathrm{ml})$ for $0,1,3$ or $10 \mathrm{~min}$. In control experiments, epithelial and fibroblast cells were preincubated in serum-free medium for $1 \mathrm{~h}$ then treated with control vehicle (C), $100 \mathrm{ng} / \mathrm{ml} \mathrm{bGH} \mathrm{(G)} \mathrm{or} 3 \mathrm{ng} / \mathrm{ml}$ hEGF (E) for $3 \mathrm{~min}$. Detergent lysates were separated through reducing $7 \cdot 5 \%$ polyacrylamide gels, transferred to nitrocellulose membrane, probed with an antiphosphotyrosine antibody and detected with ECL. The positions of molecular mass markers are indicated. Arrows indicate tyrosine-phosphoproteins produced in response to $\mathrm{bGH}$ or $\mathrm{EGF}$.

changes in tyrosine phosphorylation using Western analysis. Epithelia responded to bGH with an induction of tyrosine phosphorylation in specific proteins from $42-46 \mathrm{kDa}$ similar to those which have been reported previously (Moller et al. 1992, Winston \& Bertics 1992; Fig. 2). This demonstrates that bGH is able to stimulate a receptor coupled to a kinase system. There was no stimulation with the manipulations required by the addition of medium and vehicle solutions in control cultures. Fibroblasts had no change in phosphorylation following bGH stimulation at all concentrations of bGH (3-300 ng/ml, data not shown). Despite a lack of GHR activity in the fibroblasts, an increase in phosphorylation consistent with the $170 \mathrm{kDa}$ EGF receptor and the $60 \mathrm{kDa} \mathrm{SHC}$ adaptor protein was seen following stimulation with EGF, confirming that the fibroblasts were capable of mounting a kinase response to EGF but not to bGH (Fig. 2). 


\section{Fetal lung epithelia produce IGFBP-2 in response to bGH}

In previous studies we found that IGFBP-2 and Sp-A were products of fetal lung epithelia and thus potential targets for regulation by $\mathrm{GH}$. In order to investigate late events in $\mathrm{GH}$ stimulation, primary cell cultures of fetal day 19 lung epithelia and fibroblasts were separately incubated for $24 \mathrm{~h}$ in serum-free medium with or without bGH (100 ng/ $\mathrm{ml}$ ) and total RNA extracted. Northern analysis for the $1.7 \mathrm{~kb}$ IGFBP-2 mRNA demonstrated an approximately $50 \%$ increase with bGH stimulation in epithelia $(P<0 \cdot 01$, Fig. 3). In contrast, Sp-A mRNA was undetectable in both control and treated epithelia. No IGFBP-2 mRNA was seen in the bGH-treated and control fibroblasts, again indicating a lack of GHR activity in the fibroblasts.

\section{IGFBP-2}
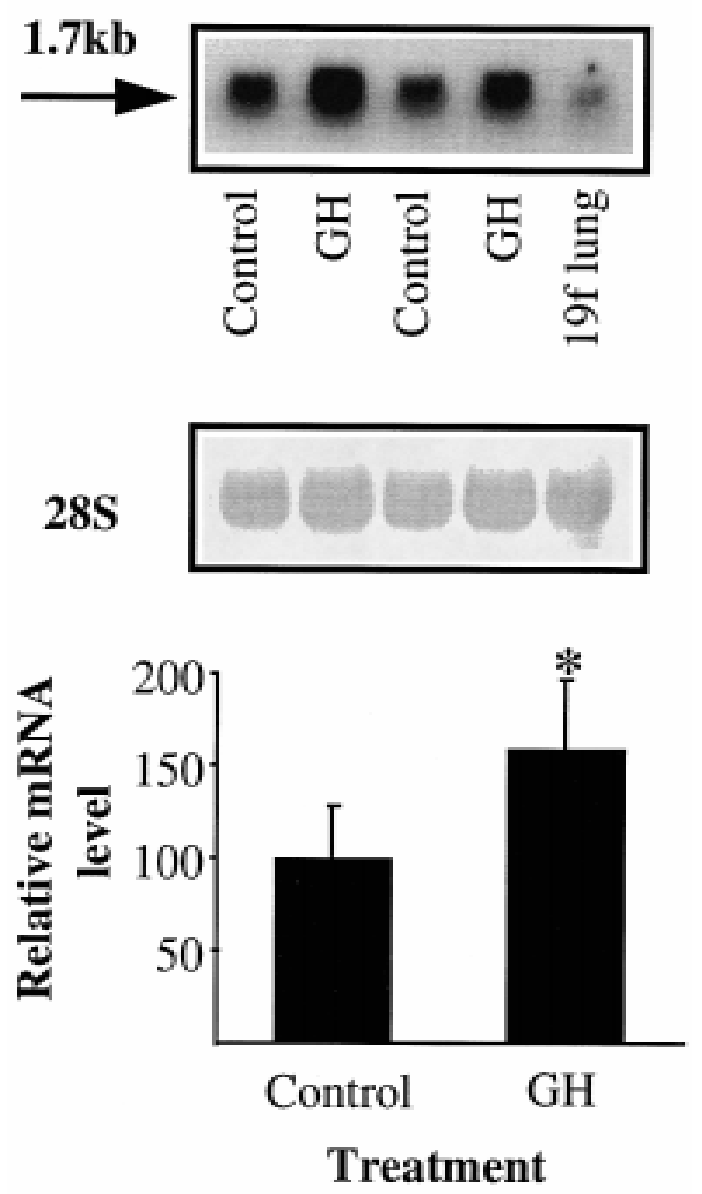

\section{Suppression of GH response by serum in cultured cells}

We had difficulty in demonstrating a response to bGH by lung epithelia in vitro unless all serum was removed. It is known that serum has a number of modifying effects on a wide variety of cell types. We therefore investigated the effect of serum on primary cell cultures of fetal lung epithelia. These were incubated for $24 \mathrm{~h}$ in medium supplemented with $0 \%, 1 \%$ or $10 \%$ serum with or without bGH $(100 \mathrm{ng} / \mathrm{ml})$. Total RNA was then extracted for Northern analysis. The relative abundance of IGFBP-2 mRNA in fetal lung epithelial cells was greatest in those grown in serum-free medium. Treatment with bGH resulted in an increase in IGFBP-2 gene expression in fetal lung epithelia only in serum-free conditions. No significant response to bGH was seen in $1 \%$ or $10 \%$ serum. There was a trend towards a decrease in IGFBP2 mRNA levels in $1 \%$ serum and a significant decrease in 10\% serum (Table 2). Thus serum moderates the response of the epithelia in terms of IGFBP-2 production and inhibits their ability to respond to $\mathrm{bGH}$.

\section{Ligand and Western blot analyses of IGFBP-2}

To confirm that the change in IGFBP-2 mRNA seen in the fetal lung epithelia was reflected in a change in protein levels, primary cell cultures of fetal day 19 lung epithelia and fibroblasts were grown for $24 \mathrm{~h}$ in serum-free medium with or without bGH $(100 \mathrm{ng} / \mathrm{ml})$. Conditioned medium was then removed and subjected to ligand blot analysis.

FIGURE 3. IGFBP-2 mRNA response to GH in day $19 \mathrm{f}$ fetal lung epithelia in vitro. Lung tissues were dissected and epithelial cells prepared as described in Materials and Methods. Cells were preincubated in serum-free media for $1 \mathrm{~h}$ then treated with bGH (100 ng/ml) for $24 \mathrm{~h}$. Total RNA was extracted and aliquots $(10 \mu \mathrm{g})$ were separated on denaturing $1 \%$ agarose gels and transferred to nylon membrane. They were probed with

${ }^{32} \mathrm{P}$-labelled probe for IGFBP-2, washed to the appropriate stringency and autoradiographed. The autoradiographs were analysed by scanning densitometry and the values for the $1.7 \mathrm{~kb}$ IGFBP- 2 mRNA band are presented in the histogram relative to the values for the methylene blue stained 28S RNA band (in arbitrary units). The histogram shows that stimulation with $\mathrm{bGH}$ resulted in a significant increase of approximately $50 \%$ in IGFBP-2 mRNA (*P<0.01, $n=4$, Student's $t$-test). The fifth lane (mRNA from 19f whole fetal lung) was included for comparison and demonstrates the high IGFBP-2 mRNA activity of epithelia. 
TABLE 2. IGFBP-2 mRNA response to bGH in primary cell cultures of epithelia from fetal day 19 rat lung incubated in the presence of $0,1 \%$ and $10 \%$ serum and with or without bGH $(100 \mathrm{ng} / \mathrm{ml})$ for 24 hours. Results are expressed as percentage (means \pm s.D.) of serum-free control ( $n=3$ in each group)

\begin{tabular}{|c|c|c|c|}
\hline & Serum free & $1 \%$ Serum & $10 \%$ Serum \\
\hline Control & 100 & $89 \pm 26$ & $72 \pm 36 *$ \\
\hline GH & $150 \pm 27 *$ & $109 \pm 32$ & $82 \pm 42$ \\
\hline
\end{tabular}

* $P<0 \cdot 05$ (ANOVA) compared with serum-free control.

Total RNA was extracted, separated and probed for IGFBP-2 by Northern analysis. The densitometric measurements of IGFBP-2 on autoradiographs were normalised against $28 \mathrm{~S}$ as described in Materials and Methods.

Treatment of fetal lung epithelia with bGH resulted in an approximately $50 \%$ increase in ${ }^{125}$ I-IGF-II binding to a $32 \mathrm{kDa}$ band which corresponds to IGFBP-2 (Fig. 4a) as reported previously (Mouhieddine et al. 1994). Fibroblasts secreted small amounts of binding proteins that were seen with long exposure of the autoradiographs but these did not change with GH stimulation (data not shown).

Others have shown that the $32 \mathrm{kDa}$ band can be attributed to IGF binding proteins other than IGFBP-2 (Price et al. 1993). To identify clearly the $32 \mathrm{kDa}$ band and to investigate whether the change in ligand binding activity was reflected in absolute protein levels of IGFBP-2, a Western blot was performed. Analysis of the immunopositive signal revealed that the levels of IGFBP-2 protein increased approximately $40 \%$ with bGH stimulation in the epithelia (Fig. 4b). No immunopositive IGFBP-2 activity was seen in fibroblast cultures. In the fetal lung epithelia, therefore, GH induced tyrosine phosphorylation and increased the concentrations of functional and absolute levels of IGFBP-2 while in the fibroblasts there were no detectable effects of $\mathrm{GH}$.

\section{DISCUSSION}

The primary aim of this study was to demonstrate functional activity for GHR in the fetal lung. We have shown that GHR is able to activate changes in tyrosine phosphorylation of in vitro cultures of fetal lung epithelia and that one of the GHR functions may be to regulate IGFBP-2 production by these cells. We have also demonstrated the presence of GHR messenger RNA in fetal rat lung late in gestation, and that this decreases towards term but increases again after birth. $\mathbf{a}$

Ligand Binding



Control GH
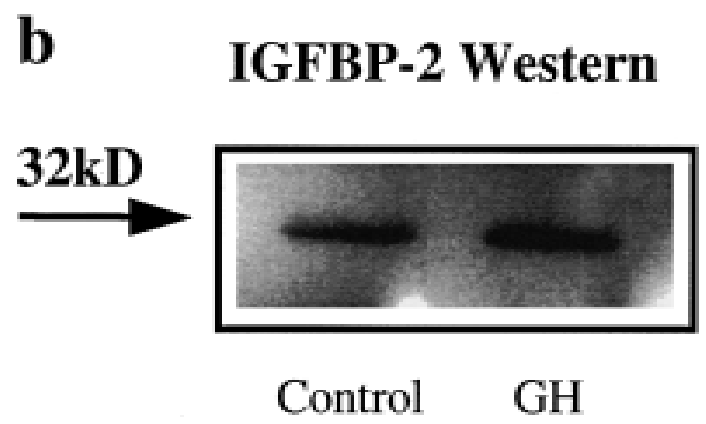

FIGURE 4. Ligand binding activity (a) and immunochemical identification (b) of IGFBP-2 in media after bGH stimulation of fetal lung epithelia in vitro. Lung tissues were collected on 19f, dissected and epithelial cells prepared as described in Materials and Methods. Cells were preincubated in serum-free media for $1 \mathrm{~h}$ then treated with bGH $(100 \mathrm{ng} / \mathrm{ml})$ for $24 \mathrm{~h}$.

Conditioned medium was dialysed, lyophilised and resuspended. Samples $(10 \mu \mathrm{g}$ protein) were separated on $12 \%$ polyacrylamide gels under non-reducing conditions, transferred to nitrocellulose membranes, incubated with

${ }^{125}$ I-IGF-II, washed and exposed against X-ray film for 24-72 h (Hossenlopp et al. 1986). The membrane was then treated to remove bound ${ }^{125}$ I-IGF-II as described in Materials and Methods, probed with an antibody to IGFBP-2 and visualised with ECL. Stimulation of epithelia with bGH resulted in an approximately $50 \%$ $(P<0 \cdot 01, n=2$, Student's $t$-test $)$ increase in ${ }^{125} \mathrm{I}-\mathrm{IGF}$-II binding to the $32 \mathrm{kDa}$ protein. Western analysis of the same blots using a specific antisera confirmed that this was due to an increase in IGFBP-2 protein. Ligand and Western analyses were repeated two or more times.

Although there are higher levels of $\mathrm{GH}$ in fetal blood than in the neonatal circulation (Rieutort 1974, Gluckman et al. 1981), animal and human studies indicate that $\mathrm{GH}$ has only minimal effects on growth of the whole fetus or individual organs such as the lung (Kim et al. 1993).

Despite initial reports of an absence of GHR in fetal tissues, mRNA and protein for GHR together 
with GHBP have been found in fetal tissues including lung epithelia by immunohistochemistry and in situ hybridisation (Garcia-Aragon et al. 1992, Edmondson et al. 1995). However this approach does not distinguish between GHR and GHBP, nor does it provide evidence for functional activity of the receptor in fetal tissues.

In the fetal rat, lung growth appears to be controlled predominantly by endopulmonary processes, while lung maturation is largely determined by changes in circulating glucocorticoids, thyroid hormones and $\beta$-agonists (Mendelson \& Boggaram 1991, Minoo \& King 1994). The glandular and canalicular phases of lung development, up to day 19 or 20 of gestation, are periods of rapid lung cell proliferation (Buch et al. 1991). In the present study we observed a significant decrease in the expression of GHR when the decrease in cell proliferation occurred at the onset of the saccular phase in the rat. After birth, in the alveolar phase, growth and maturation of the lung occur concurrently and in this phase we observed a significant increase in GHR mRNA levels.

This pattern of GHR expression closely follows that of the IGF system in the fetal lung during the perinatal period, indicating that GHR may be involved in the regulation of components of the IGF system (Batchelor et al. 1995). In the fetal lung IGF-I, IGFBP-2 and IGFBP-4 have similar ontogenic profiles (Batchelor et al. 1995 and Fig. 1). However, only IGFBP-2 is expressed in the fetal lung epithelia (Klempt et al. 1992). This suggests that the decrease in IGFBP-2 in the fetal lung epithelia towards term results from decreased GHR activity. Marker genes for the surfactant system, such as $\mathrm{Sp}-\mathrm{A}$, increase in late gestation (Buch et al. 1991, Mendelson \& Boggaram 1991, Batchelor et al. 1995). It is unlikely that GHR is involved in stimulating surfactant or Sp-A synthesis, as the levels of Sp-A mRNA and protein increase near term when GHR decreases (Batchelor et al. 1995 and Fig. 1).

Many studies investigating GHR in the fetus have concentrated almost exclusively on the liver. In the present study we found that the fetal rat lung has higher levels of mRNA for GHR than the liver, with GHR mRNA levels being twice that of the GHBP. This is unlike the liver, where levels of GHR and GHBP are approximately equal. Butler et al. (1996) have also found that various organs have different mRNA ratios of GHR to GHBP. They found that when the GH-deficient rat was compared with normal controls, GHBP and GHR expression were decreased in liver. However, in the heart, muscle and kidney, GHR expression was unchanged and GHBP expression was significantly increased. They concluded that the GHR gene is regulated in a complex organ-specific manner and suggest that these differences in expression reflect differences in the local physiological function of $\mathrm{GH}$.

The evidence supporting a role for GH in fetal life, however, has been largely inferred from the detection of the GHR and GHBP by histochemical techniques. However, it must be recognised that although immunohistochemistry is often a reliable indicator of native protein, it does not discriminate between the receptor and binding protein (GarciaAragon et al. 1992, Edmondson et al. 1995) or demonstrate any functional activity.

Fetal lung fibroblasts and epithelia appear to retain their phenotype in culture with regard to the IGF system, providing the conditions are carefully controlled (Price et al. 1993, Batchelor et al. 1995). These primary cultures of rat fetal lung cells have been used in similar experiments to investigate a variety of growth factors and post-receptor mechanisms (Torday \& Kourembanas 1990, Buch et al. 1991, Minoo \& King 1994) and are a useful model for endocrine and paracrine interactions (Torday \& Kourembanas 1990, Price et al. 1993, Batchelor et al. 1995). Here we have used the same model to provide critical evidence of a role for $\mathrm{GH}$ in the fetal compartment.

The presence of GHR mRNA in both fetal lung epithelia and fibroblast was unexpected because descriptions of immunohistochemical and in situ hybridisation images (Garcia-Aragon et al. 1992, Edmondson et al. 1995) suggest that only epithelia express GHR in the fetal lung. In contrast, IGF-I is expressed only in the fibroblasts and in these cells there may be a role for $\mathrm{GH}$ in the regulation of IGF-I (Edmondson et al. 1995). Thus GHR could function in fibroblasts to regulate IGF-I but this is very unlikely in epithelia.

An alternative strategy was required to uncover a role for $\mathrm{GH}$ in epithelia. Changes in tyrosine phosphorylation have been used to identify GHR activity in a number of studies (Stred et al. 1992, Winston \& Bertics 1992, Clayton et al. 1994). In these, GH stimulation resulted in the phosphorylation of certain intracellular proteins, such as the GH receptor, JAK2 kinase (Wang et al. 1993) and the mitogen-activated protein (MAP) kinases (Moller et al. 1992, Winston \& Bertics 1992).

In the fetal lung epithelial cells $\mathrm{GH}$ stimulated tyrosine phosphorylation in two low molecular weight proteins which were undetectable in control experiments. This response indicates that the receptor is active in the fetal lung. We did not detect phosphorylation changes in high molecular weight proteins. These could be masked by the high 
background of this technique for demonstrating phosphorylated proteins within the cell. Our experience is that the mRNA for GHR is of low abundance in this cell model, making it even more likely that the signal for phosphorylated GHR is masked. We also cannot discount the possibility that the changes in phosphorylation may be influenced by changes in phosphatase activity; however we could not distinguish any bands that were decreased with $\mathrm{GH}$ stimulation in epithelia.

No kinase stimulation was seen in fibroblasts despite the presence of GHR mRNA. This raises the possibility that the mRNA is not translated into functional protein in fibroblasts. Certainly kinase activity can be demonstrated in fibroblasts since there was a strong signal in response to EGF stimulation, with the induction of bands at 170 and $60 \mathrm{kDa}$ corresponding to the EGF receptor and the SHC protein (Pelicci et al. 1992, Warburton et al. 1992). That functional GHR activity was present in lung epithelia is consistent with previously reported immunohistochemical images of GHR and GHBP which show the presence of these proteins only on the epithelia in fetal lung (Garcia-Aragon et al. 1992). We speculate that the $42-46 \mathrm{kDa}$ phosphorylated proteins are the MAP kinases which are known to become phosphorylated following $\mathrm{GH}$ stimulation of certain cell lines (Moller et al. 1992, Winston \& Bertics 1992).

It is also possible, but unlikely, that other receptors may be responsible for the phosphorylation seen with GH. Prolactin receptors and placental lactogen receptors were once regarded as potential receptors for $\mathrm{GH}$ in the fetal compartment (Grumbach et al. 1968). However, bGH does not bind to the rat prolactin receptor (Barash et al. 1988) and binding studies using placental lactogen indicate that there are no binding sites for the placental lactogen receptor in fetal rat lung (Freemark et al. 1993). Thus we can conclude that GHR is active in the epithelia of fetal lung and suggest that GHR may be active in other fetal tissues.

The fetal lung epithelia responded to bGH with increased tyrosine kinase activity and an increase in IGFBP-2 mRNA and protein. Of the many cells and tissues studied in the rat for their response to $\mathrm{GH}$, only adipocyte precursor cells responded to GH with increased IGFBP-2 (Peter et al. 1993) and tyrosine kinase stimulation (Winston \& Bertics 1992). In previous studies insulin and glucocorticoids altered IGFBP-2 mRNA levels in rat tissues (Ooi et al. 1990, Price et al. 1992), but in the rat lung IGFBP-2 was unaffected by glucocorticoids (Price et al. 1992). The stimulation of IGFBP2 mRNA and protein by GH raises the possibility that $\mathrm{GH}$ regulates IGF activity in the epithelial environment through IGFBP-2 which has been observed on the epithelial lumen of the lung (Hill et al. 1989). The IGFBP-2 in blood may not have access to the epithelia in vivo, which are sequestered behind a basement membrane and are not in contact with fetal blood. This is one reason why it is appropriate in biological terms to limit the exposure of cells in vitro to serum components since the cells may normally have no access to blood in vivo except, for example, in inflammation or trauma. We chose to study GHR function with a range of serum concentrations and found that serum may alter the response to $\mathrm{GH}$, certainly enough to mask its effect on IGFBP-2 and tyrosine kinase activity. Similarly it has been reported that in serum-free conditions, $\mathrm{GH}$ increases IGFBP-2 protein levels in ovine costal growth plate chondrocytes but not in dermal fibroblasts (Borromeo et al. 1996). The inhibition by serum could be due to a relative excess of other growth factors or proteins in fetal bovine serum that alter GHR directly or affect the coupling of downstream activity. However, it is unlikely to be IGF-I, IGF-II, insulin or dexamethasone as these factors have been reported not to alter IGFBP-2 levels in epithelia in vitro (Price et al. 1993). It is possible that GHBP in the serum supplement added with the culture medium may form a heterodimer with GH and the GHR on the epithelia forming an inactive receptor complex (Herington et al. 1994).

It is sometimes found that changes in mRNA expression do not translate into changes in functional protein production or activity (Jansen et al. 1995). We chose to verify that the changes induced by $\mathrm{GH}$ on IGFBP-2 mRNA expression were translated into functional protein activity by ligand and Western blot analyses. The confirmation of activity and identity of IGFBP-2 by ligand blot and Western analysis confirms that the phosphorylation changes are associated with changes in specific protein synthesis. The Western analysis confirms that the increase in ${ }^{125} \mathrm{I}-\mathrm{IGF}$-II binding activity is indeed due to increased levels of IGFBP-2. It is prudent to consider that this response in IGFBP-2 may not be critical and that other more important metabolic and synthetic activities may be affected.

It is perhaps not surprising that only low amounts of other IGFBPs were detected unless the autoradiograph was left for long exposures. IGFBP-2 is the major functional IGF binding protein identified in vivo in fetal blood, amniotic fluid and in the fetal lung epithelia (Hill et al. 1989, Gargosky et al. 1990, Klempt et al. 1992, Batchelor et al. 1995). The increase in lung epithelial IGFBP-2 
with GH stimulation is also consistent with descriptive data which show that GHR and IGFBP-2 are coordinately regulated throughout the perinatal period (Batchelor et al. 1995 and Fig. $1)$. The absence of stimulation in fibroblasts is consistent with a report that $\mathrm{GH}$ failed to increase IGFBP-2 protein levels in dermal fibroblasts (Borromeo et al. 1996).

Another product of the fetal lung epithelia, Sp-A, was not affected by stimulation with GH. In ontogeny studies the Sp-A expression in fetal lung tissues increases towards term when GHR decreases, and the surfactant system is generally considered to respond to glucocorticoid, thyroid and $\beta$-adrenergic hormones which increase at this time (Mendelson \& Boggaram 1991). The receptor systems for all these endocrine agents appear to be present in fetal lung epithelia, whether in the same cells or in different populations of lung epithelia, independently influencing IGFBP-2 and Sp-A production.

It has also been suggested that GH may have an effect on glycogen metabolism in fetal lung by increasing phosphorylase A activity which is needed for the mobilisation of glucose from glycogen which occurs in lung epithelia near term (Jost et al. 1979, Bourbon \& Jost 1982).

In previous studies we found that IGFBP-2 in lung epithelia decreased towards term (Klempt et al. 1992, Batchelor et al. 1995). Others have suggested, from in vitro studies, that decreased levels of IGF-I lead to increased IGFBP-2 production by fetal lung epithelia (Mouhieddine et al. 1994), the opposite of what might be predicted from our previous results where IGF-I and IGFBP-2 mRNA in fetal lung decreased together (Batchelor et al. 1995). The experiments reported here indicate that a more likely cause of decreased IGFBP-2 may be decreased GHR activity and thus a decreased response to circulating $\mathrm{GH}$.

We conclude that the expression of GHR mRNA in the fetal lung, the kinase response of epithelia to $\mathrm{bGH}$ and the increase in IGFBP-2 activity support the hypothesis that GHR is active and functional within the epithelia of fetal lung.

\section{ACKNOWLEDGEMENTS}

We thank M M Rechler for providing the IGFBP-2 probe, C Roberts for the IGF-I probe, W R Baumbach for the GHR/GHBP probe, A Logan for the cyclophilin probe and $\mathrm{S}$ Buch for the Sp-A probe. Funding was provided by the Health Research Council of New Zealand and by the National Child Health Research Foundation of New
Zealand (NCHRF). David Batchelor received a Postgraduate Stipend from the NCHRF. Rohan Lewis received a Postgraduate Stipend from the National Heart Foundation of New Zealand.

\section{REFERENCES}

Barash I, Cromlish W \& Posner BI 1988 Prolactin (PRL) receptor induction in cultured rat hepatocytes: dual regulation by PRL and growth hormone. Endocrinology 122 1151-1158.

Batchelor DC, Hutchins A, Klempt M \& Skinner SJM 1995 Developmental changes in the expression patterns of insulin-like growth factors, type 1 IGF receptor and IGF binding proteins-2 and -4 in perinatal rat lung. Fournal of Molecular Endocrinology 15 105-115.

Baumbach WR, Horner DL \& Logan JS 1989 The growth hormone-binding protein in rat serum is an alternatively spliced form of the rat growth hormone receptor. Genes and Development 3 1199-1205.

Borromeo V, Bramani S, Holder AT, Carter C, Secchi C \& Beattie J 1996 Growth hormone stimulates the secretion of insulin-like growth factor binding protein-2 (IGFBP-2) by monolayer cultures of sheep costal growth plate chondrocytes. Molecular and Cellular Biochemistry 162 145-151.

Bourbon J \& Jost A 1982 Control of glycogen metabolism in the developing fetal lung. Pediatric Research 16 50-56.

Brown AL, Chiariotti L, Orlowski CC, Mehlman T, Burgess WH, Ackerman EJ, Bruni CB \& Rechler MM 1989 Nucleotide sequence and expression of a cDNA clone encoding a fetal rat binding protein for insulin-like growth factors. Fournal of Biological Chemistry 264 5148-5154.

Buch S, Jones C, Sweezey N, Tanswell K \& Post M 1991 Platelet-derived growth factor and growth-related genes in rat lung. I. Developmental expression. American fournal of Respiratory Cell and Molecular Biology 5 371-376.

Butler AA, Funk B, Breier BH, LeRoith D, Roberts CTJ \& Gluckman PD 1996 Growth hormone (GH) status regulates $\mathrm{GH}$ receptor and $\mathrm{GH}$ binding protein $\mathrm{mRNA}$ in a tissueand transcript-specific manner but has no effect on insulin-like growth factor-I receptor mRNA in the rat. Fournal of Molecular and Cellular Endocrinology 116 181-189.

Clayton PE, Day RN, Silva CM, Hellmann P, Day KH \& Thorner MO 1994 Growth hormone induces tyrosine phosphorylation but does not alter insulin-like growth factor-I gene expression in human IM9 lymphocytes. Fournal of Molecular Endocrinology 13 127-136.

Currie MJ, Bassett NS, Breier BH, Klempt M, Min SH, Mackenzie DD, McCutcheon SN \& Gluckman PD 1996 Differential effects of maternal ovine placental lactogen and growth hormone $(\mathrm{GH})$ administration on $\mathrm{GH}$ receptor, insulin-like growth factor (IGF)-I and IGF binding protein-3 gene expression in the pregnant and fetal sheep. Growth Regulation 6 123-129.

Danielson PE, Forss-Petter S, Brow MA, Calavetta L, Douglass J, Milner RJ \& Sutcliffe JG 1988 p1B15: a cDNA clone of the rat mRNA encoding cyclophilin. $D N A 7$ 261-267.

Edmondson SR, Werther GA, Russell A, LeRoith D, Roberts CTJ \& Beck F 1995 Localization of growth hormone receptor/binding protein messenger ribonucleic acid (mRNA) during rat fetal development: relationship to insulin-like growth factor-I mRNA. Endocrinology $1364602-4609$. 
Foster CM, Hale PM, Jing HW \& Schwartz J 1988 Effects of human growth hormone on insulin-stimulated glucose metabolism in 3T3-F442A adipocytes. Endocrinology 123 1082-1088.

Freemark M, Kirk K, Pihoker C, Robertson MC, Shiu RP \& Driscoll P 1993 Pregnancy lactogens in the rat conceptus and fetus: circulating levels, distribution of binding, and expression of receptor messenger ribonucleic acid. Endocrinology 133 1830-1842.

Garcia-Aragon J, Lobie PE, Muscat GEO, Gobius KS, Norstedt G \& Waters MJ 1992 Prenatal expression of the growth hormone $(\mathrm{GH})$ receptor/binding protein in the rat: a role for $\mathrm{GH}$ in embryonic and fetal development? Development 114 869-876.

Gargosky SE, Walton PE, Wallace JC \& Ballard FJ 1990 Characterization of insulin-like growth factor-binding proteins in rat serum, lymph, cerebrospinal and amniotic fluids, and in media conditioned by liver, bone and muscle cells. Fournal of Endocrinology 127 391-400.

Gluckman PD, Grumbach MM \& Kaplan SL 1981 The neuroendocrine regulation and function of growth hormone and prolactin in the mammalian fetus. Endocrine Reviews 2 363-395.

Gluckman PD, Gunn AJ, Wray A, Cutfield W, Chatelain PG, Guilbaud O, Ambler GR, Wilton P \& Albertsson Wikland K 1992 Congenital idiopathic growth hormone deficiency is associated with prenatal and early postnatal growth failure. Fournal of Pediatrics 121 920-923.

Grumbach MM, Kaplan SL, Sciarra JJ \& Burr IM 1968 Chorionic growth hormone-prolactin (CGP): secretion, disposition, biological activity in man, and postulated function as the 'growth hormone' of the second half of pregnancy. Annals of New York Academy of Sciences 148 $501-531$

Han VKM, D’Ercole AJ \& Lund PK 1987 Cellular localization of somatomedin (insulin-like growth factor) messenger RNA in the human fetus. Science 236 193-197.

Herington AC, Ymer SI, Stevenson JL \& Roupas P 1994 Growth hormone receptor/binding protein: physiology and function. Proceedings of the Society for Experimental Biology and Medicine 206 238-242.

Hill DJ, Clemmons DR, Wilson S, Han VK, Strain AJ \& Milner RD 1989 Immunological distribution of one form of insulin-like growth factor (IGF)-binding protein and IGF peptides in human fetal tissues. Fournal of Molecular Endocrinology 2 31-38.

Hossenlopp P, Seurin D, Segovia-Quinson B, Hardouin S \& Binoux M 1986 Analysis of serum binding proteins using Western blotting - use of the method for titration of the binding proteins and competitive binding studies. Analytical Biochemistry 154 138-143.

Jakubowski M, Blum M \& Roberts JL 1991 Postnatal development of gonadotropin-releasing hormone and cyclophilin gene expression in the female and male rat brain. Endocrinology 128 2702-2708.

Jansen M, de Moor CH, Sussenbach JS \& Van den Brande JL 1995 Translational control of gene expression. Pediatric Research 37 681-686.

Jones JI \& Clemmons DR 1995 Insulin-like growth factors and their binding proteins: biological actions. Endocrine Reviews $163-34$.

Jost A, Rieutort M \& Bourbon J 1979 Plasma growth hormone in the rabbit fetus. Relation to maturation of the liver and lung. Comptes Rendus des Seances de l'Academie des Sciences Serie D, Sciences Naturelles 288 347-349.

Kaplan SL, Grumbach MM \& Shepard TH 1972 The ontogenesis of human fetal hormones. I. Growth hormone and insulin. Fournal of Clinical Investigation 51 3080-3093.
Kim JD, Nanto Salonen K, Szczepankiewicz JR, Rosenfeld RG \& Glasscock GF 1993 Evidence for pituitary regulation of somatic growth, insulin-like growth factors-I and -II, and their binding proteins in the fetal rat. Pediatric Research 33 144-151.

Klempt M, Hutchins AM, Gluckman PD \& Skinner SJ 1992 IGF binding protein-2 gene expression and the location of IGF-I and IGF-II in fetal rat lung. Development $\mathbf{1 1 5}$ $765-772$.

Lowe WLJ, Lasky SR, LeRoith D \& Roberts CTJ 1988 Distribution and regulation of rat insulin-like growth factor-I messenger ribonucleic acids encoding alternative carboxyterminal E-peptides: evidence for differential processing and regulation in liver. Molecular Endocrinology 2 528-535.

Markwell MA, Haas SM, Bieber LL \& Tolbert NE 1978 A modification of the Lowry procedure to simplify protein determination in membrane and lipoprotein samples. Analytical Biochemistry 87 206-210.

Mendelson CR \& Boggaram V 1991 Hormonal control of the surfactant system in fetal lung. Annual Review of Physiology 53 415-440.

Minoo P \& King RJ 1994 Epithelial-mesenchymal interactions in lung development. Annual Review of Physiology 56 $13-45$.

Moller C, Hansson A, Enberg B, Lobie PE \& Norstedt G 1992 Growth hormone $(\mathrm{GH})$ induction of tyrosine phosphorylation and activation of mitogen-activated protein kinases in cells transfected with rat GH receptor cDNA. Fournal of Biological Chemistry 267 23403-23408.

Mouhieddine OB, Cazals V, Maitre B, Le Bouc Y, Chadelat K \& Clement A 1994 Insulin-like growth factor-II (IGF-II), type 2 IGF receptor, and IGF-binding protein-2 gene expression in rat lung alveolar epithelial cells: relation to proliferation. Endocrinology 135 83-91.

Ooi GT, Orlowski CC, Brown AL, Becker RE, Unterman TG \& Rechler MM 1990 Different tissue distribution and hormonal regulation of messenger RNAs encoding rat insulin-like growth factor-binding proteins-1 and -2 . Molecular Endocrinology 4 321-328.

Palmiter RD, Norstedt G, Gelinas RE, Hammer RE \& Brinster RL 1983 Metallothionein-human GH fusion genes stimulate growth of mice. Science 222 809-814.

Pelicci G, Lanfrancone L, Grignani F, McGlade J, Cavallo F, Forni G, Nicoletti I, Pawson T \& Pelicci PG 1992 A novel transforming protein (SHC) with an $\mathrm{SH} 2$ domain is implicated in mitogenic signal transduction. Cell $\mathbf{7 0}$ 93-104.

Peter MA, Winterhalter KH, Boni-Schnetzler M, Froesch ER \& Zapf J 1993 Regulation of insulin-like growth factor-I (IGF-I) and IGF-binding proteins by growth hormone in rat white adipose tissue. Endocrinology 133 2624-2631.

Price WA, Stiles AD, Moats Staats BM \& D’Ercole AJ 1992 Gene expression of insulin-like growth factors (IGFs), the type 1 IGF receptor, and IGF-binding proteins in dexamethasone-induced fetal growth retardation. Endocrinology 130 1424-1432.

Price WA, Moats Staats BM, D’Ercole AJ \& Stiles AD 1993 Insulin-like growth factor binding protein production and regulation in fetal rat lung cells. American Fournal of Respiratory Cell and Molecular Biology 8 425-432.

Rieutort M 1974 Pituitary content and plasma levels of growth hormone in foetal and weanling rats. Fournal of Endocrinology 60 261-268.

Rosenbloom AL, Savage MO, Blum WF, Guevara Aguirre J \& Rosenfeld RG 1992 Clinical and biochemical characteristics of growth hormone receptor deficiency (Laron syndrome). Acta Paediatrica Scandinavica (Supplement) 383 121-124. 
Rosenfeld RG, Rosenbloom AL \& Guevara-Aguirre J 1994 Growth hormone $(\mathrm{GH})$ insensitivity due to primary $\mathrm{GH}$ receptor deficiency. Endocrine Reviews 15 369-390.

Searle TW, Murray JD \& Baker PJ 1992 Effect of increased production of growth hormone on body composition in mice: transgenic versus control. Fournal of Endocrinology 132 285-291.

Skinner SJM, Somervell CE \& Lowe C 1991 Interaction between prostacyclin and cortisol in fetal lung cells: effects on cAMP production. Prostaglandins 41 331-344.

Stiles AD \& Moats Staats BM 1989 Production and action of insulin-like growth factor-I/somatomedin $\mathrm{C}$ in primary cultures of fetal lung fibroblasts. American Fournal of Respiratory Cell and Molecular Biology 1 21-26.

Stred SE, Stubbart JR, Argetsinger LS, Smith WC, Shafer JA, Talamantes F \& Carter-Su C 1992 Stimulation by growth hormone $(\mathrm{GH})$ of $\mathrm{GH}$ receptor-associated tyrosine kinase activity. Endocrinology 130 1626-1636.

Tijssen P 1993 Hybridization after electophoretic fractionation of nucleic acids. In Laboratory Techniques in Biochemistry and Molecular Biology, pp 437-473. Ed PC van der Vliet. Amsterdam: Elsevier.

Torday JS \& Kourembanas S 1990 Fetal rat lung fibroblasts produce a TGF beta homolog that blocks alveolar type II cell maturation. Developmental Biology 139 35-41.

Wang X, Moller C, Norstedt G \& Carter-Su C 1993 Growth hormone-promoted tyrosyl phosphorylation of a $121-\mathrm{kDa}$ growth hormone receptor-associated protein. Fournal of Biological Chemistry 268 3573-3579.

Warburton D, Seth R, Shum L, Horcher PG, Hall FL, Werb Z \& Slavkin HC 1992 Epigenetic role of epidermal growth factor expression and signalling in embryonic mouse lung morphogenesis. Developmental Biology 149 123-133.

Winston LA \& Bertics PJ 1992 Growth hormone stimulates the tyrosine phosphorylation of 42 and $45 \mathrm{kDa}$ ERKrelated proteins. Fournal of Biological Chemistry 267 $4747-4751$.

REVISED MANUSCRIPT RECEIVED 31 March 1998 